\title{
キラル高速液体クロマトグラフィー/大気圧化学イオン化質量分析法による グリシドール脂肪酸エステルの光学異性体分析
}

\author{
吉岡 智史 ${ }^{1}$, 西村 一彦 ${ }^{2}$, 高村 岳樹 $^{3}$, 酒々井眞澄 ${ }^{4}$, 津田 洋幸 ${ }^{4}$, 板 橋 豊 $^{\circledR 5}$
}

\begin{abstract}
キラル高速液体クロマトグラフィー/質量分析法（HPLC/MS）を用いて, 食用油に微量存在し, 安全性が 危惧されているグリシドール脂肪酸エステル（GE）の光学異性体を分離, 定量する方法を検討した. HPLC 分析には，アミロース誘導体を固定相とするカラムとアセトニトリルに少量のメタノールを添加した移動相 を使用した．MSには四重極型質量分析計を用いて，大気圧化学イオン化法で正イオンスペクトルを測定し た. その結果, 炭素数と不飽和度の異なる $\mathrm{GE}$ の光学異性体が明暸に分離され，それぞれから顕著なプロト ン化分子 $[\mathrm{M}+\mathrm{H}]^{+}$が検出された．このイオンを用いる選択イオン検出法によって，ジアシルグリセロールを 約 80 \% 含有する食用油 (DAG 油) を直接分析した結果, アシル基の異なる 5 種の GE (16:0-GE, 18:0-GE, 18:1-GE，18：2-GE，18:3-GE）が検出され，これらはいずれも $(R)$ - 異性体と $(S)$ - 異性体のほぼ等量混合 物であることが明らかになった，得られた結果から，DAG 油に含まれる GE の光学異性体は，ほぼラセミ体 の1-モノアシルグリセロールから生成するものと考えられた.
\end{abstract}

\section{1 緒言}

食用油（精製植物油）に微量含まれるグリシドール脂肪 酸エステル（GE，1-アシル-2,3-エポキシプロパン）の安全 性が危惧されており，世界的に大きな問題となってい る12)。 GE は，食用油の主成分であるトリアシルグリセ ロール（TAG）やジアシルグリセロール（DAG）が脱臭な どの精製工程で高温, 高圧下に置かれることで生成すると 考えられている2)3.

食用油に含まれる微量の GE を精確に定量することは容 易ではなく, 信頼のおける分析法の開発が緊急の課題と なっている1).これまで, $\mathrm{GE}$ の分析法がいくつか報告され ている. たとえば, Masukawa ${ }^{4) 5}$ らは食用油中の GE 2 回 の固相抽出によって濃縮した後, 逆相高速液体クロマトグ ラフィー/質量分析法 (HPLC/MS) を用いてアシル基の異 なる 5 種の GE を定量している. Weißhaar ${ }^{3)} ら は$ 食用油中 の GEをゲル沪過によって分離後，ガスクロマトグラ

\footnotetext{
${ }^{\circledR}$ E-mail : yutaka@fish.hokudai.ac.jp

${ }^{1}$ 北海道大学大学院水産科学院海洋応用生命科学分野 : 041-8611 北海道函館市港町 3-1-1

2 北海道立衛生研究所 : 060-0819 北海道札幌市北区北 19 条西 12 丁目

${ }^{3}$ 神奈川工科大学工学部応用化学科 : 243-0292 神奈川県厚木市 下荻野 1030

4 名古屋市立大学大学院医学研究科分子毒性学分野 : 467-8601 愛知県名古屋市瑞穂区瑞穂町字川澄 1

${ }^{5}$ 北海道大学大学院水産科学研究院海洋応用生命科学部門 : 0418611 北海道函館市港町 3-1-1
}

フィー/質量分析法（GC/MS）を用いて同定している. 一 方, Deutsche Gesellschaft für Fettwissenschaft (DGF, ドイ ツ脂質科学会 $)^{6)}$ は, GE を加水分解して生成する 3-モノク ロロ-1,2-プロパンジオールをフェニルホウ酸で誘導体化 した後, GC/MS を用いて GEを間接的に定量する方法を推 奨している．これらの方法は，食用油に含まれる GEの検 出と定量に有用であると思われるが, 存在可能な 1 対の光 学異性体 (Fig. 4 参照) については何も考慮されていない. $\mathrm{GE}$ の光学異性体間の生物活性の差異は明らかではないが, 光学異性体は, 一方が有効な活性を示し, もう一方が毒性 を示すなど生物に対する作用が異なる場合があることか ら，食品中の GE をリスク評価する際には，安全性が危惧 されている GE の光学異性体分析は不可欠であると考えら れる。

本研究では逆相キラル HPLC を用いて GE の光学異性体 を分離し, MS を併用して前処理なしで実試料中の GE 光学 異性体を直接分析する方法を検討した，得られた結果から $\mathrm{GE}$ 光学異性体の生成経路を推測した.

$$
2 \text { 実験 }
$$

\section{$2 \cdot 1$ 試 薬}

以下の試薬を用いた. パルミチン酸 $(16: 0)$, ステアリ ン酸 $(18: 0)$, オレイン酸 $(18: 1)$, リノール酸 $(18: 2)$, リノレン酸（18:3）（Sigma 製, 純度 $99 \%$ 以上）; パルミ チン酸グリシジル (16:0-GE, 純度 $98 \%$ 以上), オレイン 酸グリシジル（18:1-GE, 純度 $98 \%$ 以上), リノール酸グ 
リシジル（18:2-GE, 純度 $90 \%$ 以上), リノレン酸グリシ ジル（18:3-GE, 純度 $85 \%$ 以上) (和光純薬工業製) ; 4-ジ メチルアミノピリジン (DMAP), 無水硫酸ナトリウム, $N, N$-ジシクロヘキシルカルボジイミド（DCC）（ナカライ テスク製) ; $(R)_{-},(S)$ - 及びラセミ体グリシドール (Aldrich 製, 純度 $96 \sim 97 \%$ ）; DAG 高含有（約 $80 \%$ ）食用油 ${ }^{7)}$ (DAG 油, 花王製, 2008 年に函館市内の食料品店にて購入).

\section{2・2 GE 標準品の合成}

$(R)$-グリシドール， $(S)$-グリシドール及びラセミ体グリ シドール (各 $0.9 \mathrm{mmol})$, 脂肪酸 $(1.0 \mathrm{mmol})$, DCC $(1.2$ mmol $)$, DMAP (0.2 mmol) をクロロホルム $5 \mathrm{~mL}$ に溶解 し, 擋拌しながら $20{ }^{\circ} \mathrm{C} て ゙ 16$ 時間反応させた。. 沪過後, ク ロロホルムを窒素気流下で除去して得られた残温約 $20 \mathrm{mg}$ を $200 \mu \mathrm{L}$ のクロロホルムに再度溶解させた. このクロロ ホルム可溶物からシリカゲル薄層クロマトグラフィー $\left\{\right.$ Merck 製シリカゲル $60 \mathrm{~F}_{254}$ （厚さ $0.25 \mathrm{~mm}, 20 \mathrm{~cm} \times 20$ $\mathrm{cm})\}$ を用いて GE を単離した. 展開溶媒にはへキサン - ジ エチルエーテル $(60: 40, \mathrm{v} / \mathrm{v})$ を使用した. 展開後, $0.2 \%$ 2',7'-ジクロロフルオレセイン試薬を噴霧して, 紫外線照射 下で市販標準品と同一の $R_{\mathrm{f}}$ 值を示すバンドを確認し, ジエ チルエーテルを用いて抽出した．得られた GE 画分を大気 圧化学イオン化質量分析法 (APCI-MS) で確認し, その純 度を光散乱検出逆相 HPLC（HPLC/ELSD）で求めた．MS には四重極型質量分析計 LC/MS-2010EV（島津製作所製） を用い, インフュージョン法で GEのマススペクトルを $m / z 200 \sim m / z 1000$ の範囲で測定した. ネブライザーガ ス $2.5 \mathrm{~L} \mathrm{~min}^{-1}$, インターフェース温度 $400{ }^{\circ} \mathrm{C}$, 加熱ブロッ ク温度 $200{ }^{\circ} \mathrm{C}$ に設定し, 正イオンスペクトル測定した. HPLC 分析には Gemini 5u C18 110A カラム (Penomenex 製, 内径 $4.6 \mathrm{~mm}$, 長さ $25 \mathrm{~cm}$, 粒径 $5 \mu \mathrm{m})$, LC-20AD ポ ンプ (島津製作所製), カラム恒温槽 Cool Pocket (Thermo Fisher Scientific 製), 蒸発光散乱検出器 (SEDEX55, SEDERE 製）及びクロマトパック C-R6A（島津製作所製） を使用した．試料は 2-プロパノールに $1 \mathrm{mg} \mathrm{mL}^{-1}$ の濃度 になるように溶解し, その $5 \mu \mathrm{L}$ を Rheodyne 製インジェク ター（Model 7725）を用いてカラムに注入した. 移動相に はアセトニトリル/メタノール（10:90, v/v）（関東化学製 HPLC 用) を用いて $0.5 \mathrm{~mL} \mathrm{~min}$ m $^{-1}$ の流量で送液した. カラ ム温度は $20{ }^{\circ} \mathrm{C}$ とし, 検出器の温度を $50{ }^{\circ} \mathrm{C}$ (空気圧力 2.3 bar, Gain 8）に設定して溶出成分を検出した.

\section{$2 \cdot 3$ キラル HPLC/ELSD 分析}

キラル HPLC 分析には, 固定相に Amylose tris(3,5dimethylphenylcarbamate) を含むダイセル製のCHIRALPAK IA カラム（内径 $4.6 \mathrm{~mm}$, 長さ $25 \mathrm{~cm}$, 粒径 $5 \mu \mathrm{m}$ ) と $2 \cdot 2$

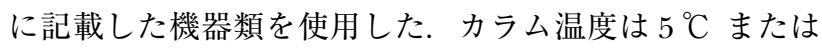

$25{ }^{\circ} \mathrm{C}$ に設定し, GE の光学異性体分離を検討した. 合成し た $\mathrm{GE}$ 標準品を 2-プロパノールに $200 \mu \mathrm{g} \mathrm{mL}{ }^{-1}$ の濃度にな るように溶解し, その $5 \mu \mathrm{L}$ を Rheodyne 製インジェクター (Model 7725) を用いてカラムに注入した. 移動相には, ア セトニトリルに少量のメタノール，2-プロパノール，エ夕 ノールまたは水（いずれも関東化学製 HPLC 用）を加えた ものを使用し (組成については $3 \cdot 1$ 参照), $0.5 \mathrm{~mL} \mathrm{~min}^{-1}$ の流量で送液した.

\section{$2 \cdot 4$ キラル HPLC/APCI-MS}

実試料（DAG 油）に含まれる GE の光学異性体の分離と 定量にはキラル HPLC/APCI-MSを使用した. キラル HPLC は $2 \cdot 3$ と同一の条件で行った. APCI-MS は $2 \cdot 2$ と同 一条件で行い, プロトン化分子を用いる選択イオン検出 （SIM）により各光学異性体を定量した．合成した GE 標準 品（ラセミ体）を2-プロパノールに0.5，1，5，10, 20, $50 \mu \mathrm{g} \mathrm{mL}{ }^{-1}$ の濃度になるように溶解し，その $5 \mu \mathrm{L}$ をオー トインジェクター用いてカラムに注入した．溶出した各光 学異性体のピーク面積を測定して検量線を作成した．検出 限界と定量限界は，それぞれ $S / N=3, S / N=10$ で求め た. DAG 油は 2-プロパノールに $30 \mathrm{mg} \mathrm{mL}^{-1}$ の濃度になる ように溶解し，その $20 \mu \mathrm{L}$ をオートインジェクターを用い てカラムに注入した。移動相を 150 分間送液して, GE の 後に溶出する多量の DAG などの夾雑物をカラムから排出 した.

\section{3 結果と考察}

\section{3・1 GE 標準品の純度検定}

インフュージョン法による MS 分析の結果, 本研究で合 成したすべての GEからベースピークとして $[\mathrm{M}+\mathrm{H}]^{+}$が検 出された。また, C18 カラムを用いた逆相 HPLC/ELSD 分 析では, いずれの試料からも単一のピークが得られ, 合成 した GE 標準品はすべて高純度であることが確認された.

\section{$3 \cdot 2$ キラル HPLC による GE の光学異性体分離}

キラル HPLC 分析に使用した CHIRALPAK IA カラムは 従来型の CHIRALPAK $\mathrm{AD}$ カラムと同様, 固定相として Amylose tris(3,5-dimethylphenylcarbamate) を含むが, 耐溶 剂性に優れ，順相と逆相の両モードで使用できる特徴を有 する ${ }^{8)}$. 本研究では, HPLC/MS でのイオン化を促進するた めに，またアシル基の異なる種々の GE の光学異性体を一 斉に分離するために逆相モードを選択した，移動相にアセ トニトリル/メタノール，アセトニトリル/2-プロパノー ル，アセトニトリル/エタノール（組成はいずれも $98.5: 1.5, \mathrm{v} / \mathrm{v})$, 及びアセトニトリル/水 $(90: 10, \mathrm{v} / \mathrm{v})$ を 用いて GE の光学異性体分離を検討した結果, アセトニト リル/メタノールで最も良い分離が得られた。たとえば, 


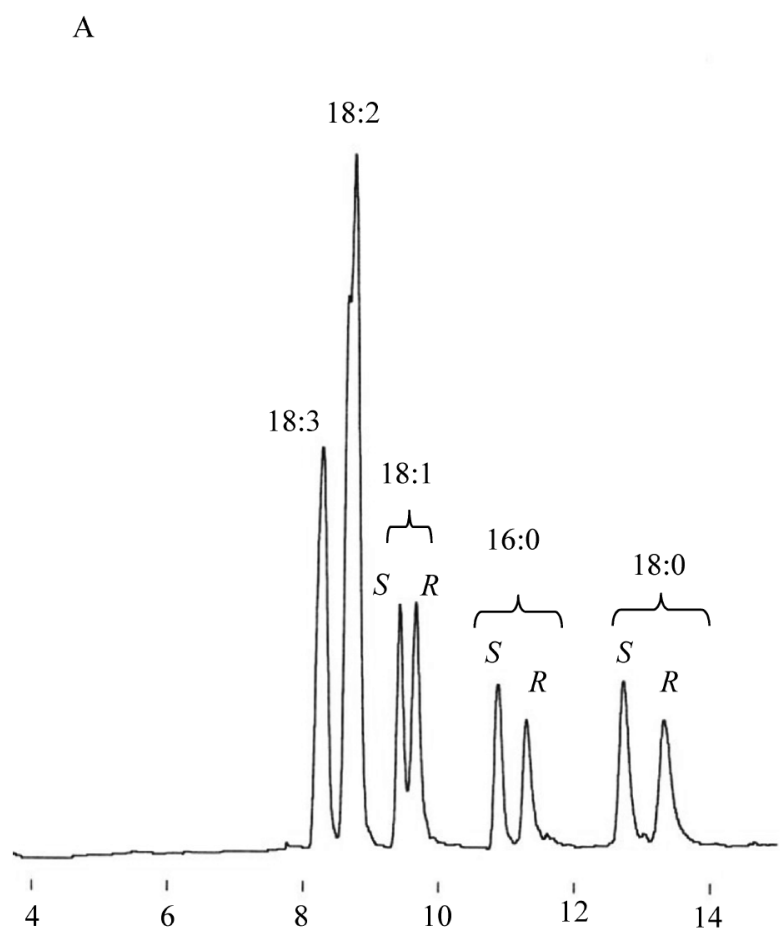

Time / $\min$

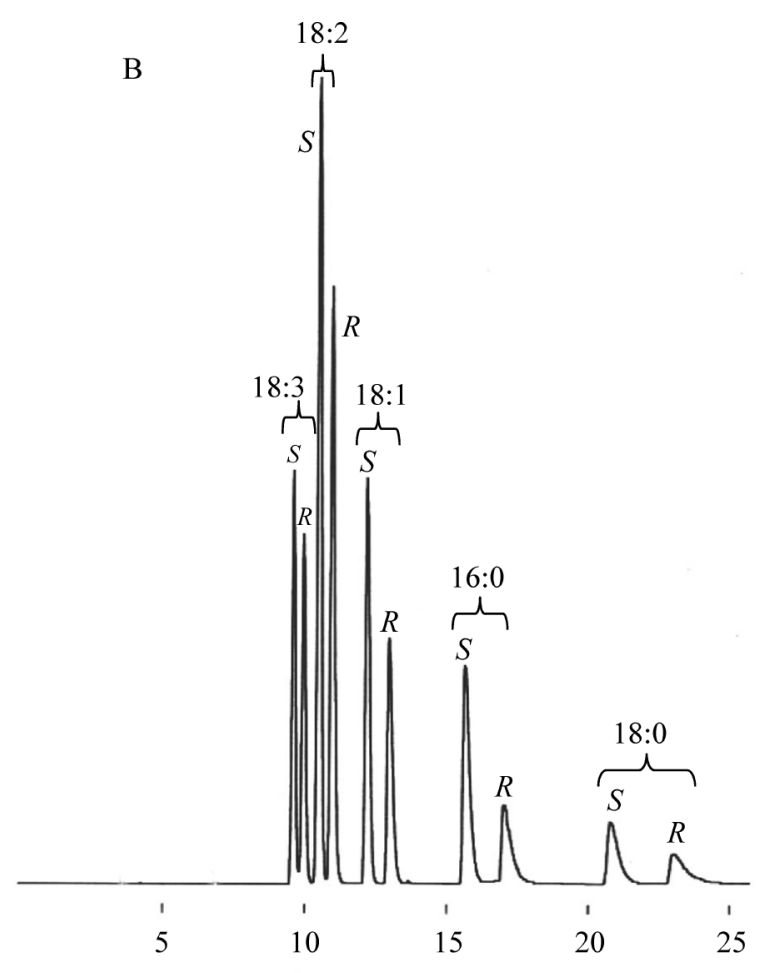

Time / $\min$

Fig. 1 Chiral-phase HPLC/ELSD profiles of racemic glycidyl fatty acid esters

$18: 3$, glycidyl linolenate ; $18: 2$, glycidyl linoleate ; $18: 1$, glycidyl oleate ; $16: 0$, glycidyl palmitate ; $18: 0$, glycidyl stearate.

Column, CHIRALPAK IA $(250 \times 4.6 \mathrm{~mm}$ i.d. $)$; Mobile phase, Acetonitrile/methanol. $\quad$ A, $90: 10(\mathrm{v} / \mathrm{v}) ; \mathrm{B}, 98.5: 1.5$ (v/v). Column temperature : A, $25{ }^{\circ} \mathrm{C} ; \mathrm{B}, 5{ }^{\circ} \mathrm{C}$. Flow rate, $0.5 \mathrm{~mL} \mathrm{~min}{ }^{-1}$.

Table 1 Chromatographic parameters of enantiomeric glycidyl fatty acid esters (GE) obtained by chiral-phase HPLC/ELSD ${ }^{\text {a) }}$

\begin{tabular}{|c|c|c|c|c|c|c|c|c|c|}
\hline \multirow{3}{*}{\multicolumn{2}{|c|}{ GE enantiomer }} & \multicolumn{8}{|c|}{ Column temperature } \\
\hline & & \multicolumn{4}{|c|}{$25{ }^{\circ} \mathrm{C}$} & \multicolumn{4}{|c|}{$5{ }^{\circ} \mathrm{C}$} \\
\hline & & $V_{\mathrm{R}}^{\mathrm{b})}$ & $k^{\text {c) }}$ & $\alpha^{\text {d) }}$ & $R_{\mathrm{S}}{ }^{\mathrm{e})}$ & $V_{\mathrm{R}}$ & $k^{\prime}$ & $\alpha$ & $R_{\mathrm{S}}$ \\
\hline \multirow{2}{*}{$16: 0$} & $S$ & 0.31 & 0.62 & \multirow{2}{*}{1.10} & \multirow{2}{*}{1.70} & 0.69 & 1.39 & \multirow{2}{*}{1.16} & \multirow{2}{*}{2.98} \\
\hline & $R$ & 0.34 & 0.69 & & & 0.81 & 1.61 & & \\
\hline \multirow{2}{*}{$18: 0$} & $S$ & 0.45 & 0.90 & \multirow{2}{*}{1.10} & \multirow{2}{*}{1.82} & 1.09 & 2.18 & \multirow{2}{*}{1.17} & \multirow{2}{*}{3.27} \\
\hline & $R$ & 0.49 & 0.99 & & & 1.27 & 2.55 & & \\
\hline \multirow{2}{*}{$18: 1$} & $S$ & 0.20 & 0.41 & \multirow{2}{*}{1.09} & \multirow{2}{*}{1.09} & 0.42 & 0.85 & \multirow{2}{*}{1.15} & \multirow{2}{*}{2.78} \\
\hline & $R$ & 0.22 & 0.44 & & & 0.49 & 0.97 & & \\
\hline \multirow{2}{*}{$18: 2$} & $S$ & - & - & \multirow[t]{2}{*}{-} & \multirow[t]{2}{*}{-} & 0.29 & 0.59 & \multirow{2}{*}{1.12} & \multirow{2}{*}{1.85} \\
\hline & $R$ & - & - & & & 0.33 & 0.66 & & \\
\hline \multirow{2}{*}{$18: 3$} & $S$ & - & - & \multirow[t]{2}{*}{-} & \multirow[t]{2}{*}{-} & 0.23 & 0.45 & \multirow{2}{*}{1.12} & \multirow{2}{*}{1.60} \\
\hline & $R$ & - & - & & & 0.25 & 0.50 & & \\
\hline
\end{tabular}

a) Mobile phase : Acetonitrile/methanol (98.5: 1.5, v/v); b) $V_{\mathrm{R}}=$ retention volume $(\mathrm{mL})$ corrected by subtracting the column void volume (Chiralpak IA, $3.35 \mathrm{~mL}$ ); c) $k^{\prime}=$ capacity ratio ; d) $\alpha=$ separation factor ; e) $R_{\mathrm{S}}=$ peak resolusion. $\quad R_{\mathrm{S}}=1.18\left(R \mathrm{t}_{2}-R \mathrm{t}_{1}\right) /\left(w_{2}+w_{1}\right)$, where $w=$ peak half width $(\min )$.

$25{ }^{\circ} \mathrm{C}$ で分析した場合, $16: 0-\mathrm{GE}, 18: 0-\mathrm{GE}$ 及び $18: 1-\mathrm{GE}$ の分離係数は，アセトニトリル/2-プロパノールではそれ ぞれ $1.38,1.40,0.78$, アトニトリル/エタノールでは $1.42,1.58,0.79$, アセトニトリル/水では $1.37,1.16,1.05$ で
あったのに対し，アセトニトリル/メタノールではいずれ の GEについても 1.70, 1.82, 1.09 と高い值が得られた. Fig. 1 に，アセトニトリル/メタノール (98.5: 1.5, v/v) を 移動相に用いて, GE のラセミ体混合物（16:0-GE， 

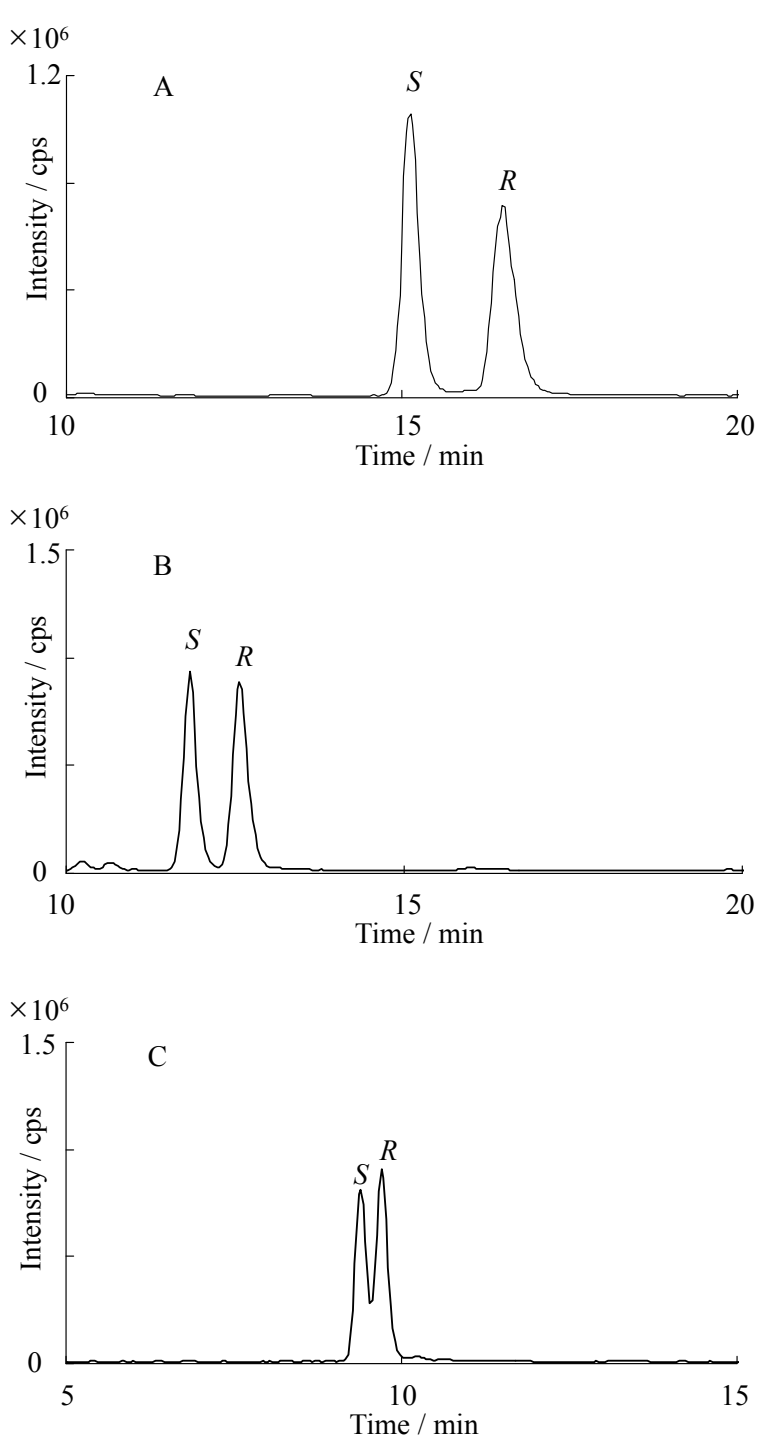

Fig. 2 Chiral-phase HPLC/APCI-MS profiles (selected ion monitoring of $[\mathrm{M}+\mathrm{H}]^{+}$) of racemic glycidyl fatty acid esters on CHIRALPAK IA

A, glycidyl palmitate $(m / z 313)$; B, glycidyl oleate ( $m / z$ 339); C, glycidyl linolenate $(m / z$ 335). Mobile phase and column temperature are the same as those in Fig. 1B. Other HPLC and MS conditions as given in text.

18:0-GE, 18:1-GE, 18:2-GE, 18:3-GE) を分析して得 られたクロマトグラムを示す. $25{ }^{\circ} \mathrm{C}$ のカラム温度で分析 した結果, $16: 0-\mathrm{GE}$ と $18: 0-\mathrm{GE}$ の光学異性体は完全に分 離されたが, 不飽和度の増加とともに GEの分離は低下し, 18: 3-GE の光学異性体分離は得られなかった (Fig. 1A). 各 $\mathrm{GE}$ の光学異性体を同時に分離するために $5{ }^{\circ} \mathrm{C}$ のカラム 温度で分析した結果, すべての GE が明瞭に分離され，飽 和及び不飽和 GE の光学異性体 10 成分の一斉分析が可能と なった（Fig. 1B）。アシル基の鎖長と不飽和度は光学異性 体の溶出順には影響を及ぼさず, いずれの GE も $(S)$ - 異性 体が先に溶出した. Morante-Zarcero ら ${ }^{9)}$ は CHIRALPAK
$\mathrm{AD}-\mathrm{H}$ カラムを用いてグリシドールの光学異性体分離を検 討した結果, ヘキサン/エタノール $(80: 20, \mathrm{v} / \mathrm{v})$ の移動相 で良好な分離が得られ (分離度, $R_{\mathrm{S}}=1.8$ ),$S$ 配置が $R$ 配 置よりも強く保持されることを報告している. GE の光学 異性体を順相移動相（ヘキサン/2-プロパノール，99：1, v/v）を用いて CHIRALPAK IA カラムで分析した場合，不 飽和 GE（18：1-GE, $18: 2-G E, 18: 3-G E ） の$ 光学異性体は 良好に分離され，逆相のときと溶出順は逆転して $(R)$ - 異 性体が先に溶出した (クロマトグラムは省略). 多糖誘導体 型固定相のキラル認識のメカニズムは十分解明されていな いが ${ }^{10)}$, Amylose tris(3,5-dimethylphenylcarbamate)による GE のキラル認識には, 水素結合形成, $\pi-\pi$ 相互作用, 双極 子-双極子相互作用などに加え, 移動相溶剂の極性が大き く関与しているものと推察される.

$\mathrm{GE}$ 光学異性体の保持容量 $\left(V_{\mathrm{R}}\right)$, 保持係数 $\left(k^{\prime}\right)$, 分離係 数 $(\alpha)$ 及び分離度 $\left(R_{\mathrm{S}}\right)$ を Table 1 に示す. GE は二重結 合数が増すにつれて極性が増大し, 溶出時間が短くなって 分離度が低下した．同様に，極性のより大きい 16 : 0-GE は 18：0-GEより早く溶出し, 分離度が低下した.このような アシル基の分離に与える影響はグリセロ脂質のキラル HPLCにおいて広く認められている ${ }^{11)}$ 12). 一般に光学異性 体は低温で良い分離が得られるが11), 本研究においてもカ ラム温度を $25{ }^{\circ} \mathrm{C}$ から $5{ }^{\circ} \mathrm{C}$ に下げることで, 不飽和 $\mathrm{GE}$ (18:1-GE, $18:$ 2-GE, $18:$ 3-GE) についてはいずれも 1.6 以上の分離度が得られ, 分離は著しく改善した（Table 1). このことから, 低温での分析は実試料中の GE 光学異性体 の分析に特に有効であると考えられた.

\section{$3 \cdot 3$ キラル HPLC-MS による GE 光学異性体の定量}

移動相にアセトニトリル/メタノール (98.5: 1.5, v/v) を用いて, カラム温度 $5{ }^{\circ} \mathrm{C}$ で, 各 $\mathrm{GE}$ 標準品をキラル HPLC/APCI-MS 分析した結果, すべての GE からプロトン 化分子 $[\mathrm{M}+\mathrm{H}]^{+}$がほぼ単一のピークとして検出された. このイオンを選択して得られた GE ラセミ体の SIMクロマ トグラムを Fig. 2 に示す. いずれのラセミ体についても ELSD 検出の場合と同様に良好な分離が得られた，GEの MS において, $[\mathrm{M}+\mathrm{H}]^{+}$をモニターした場合, APCI-MS は ESI-MS の 10 倍高感度であることが報告されている ${ }^{4)}$. 本研 究でも ESI-MS を検討したが, 適用した条件では $[\mathrm{M}+\mathrm{H}]^{+}$ は検出されず, $[\mathrm{M}+\mathrm{Na}]^{+}$がAPCI-MSで得られた $[\mathrm{M}+\mathrm{H}]^{+}$ に匹敵する感度で検出された. したがって, ESI-MSでも GEの分析は十分可能であると考えられる.

Table 2 に検出限界, 定量限界及び検量線について検討 した結果を示す. 各 GE の検量線の相関係数は 0.997 以上 であり，良好な直線関係が得られた。検出限界 $(S / N=3)$ と定量限界 $(S / N=10)$ は, それぞれ $0.2,0.67 \mu \mathrm{g} \mathrm{mL}^{-1}$ であった。 
Table 2 Limit of detection (LOD), limit of quantification (LOQ), and calibration lines obtained for enantiomeric glycidyl fatty acid esters (GE)

\begin{tabular}{|c|c|c|c|c|c|c|c|c|}
\hline \multirow{3}{*}{ GE } & \multirow{2}{*}{\multicolumn{2}{|c|}{$\frac{\mathrm{LOD}^{\mathrm{a})} / \mu \mathrm{g} \mathrm{mL}^{-1}}{\text { Enantiomer }}$}} & \multirow{2}{*}{\multicolumn{2}{|c|}{$\frac{\mathrm{LOQ}^{\mathrm{a})} / \mu \mathrm{g} \mathrm{mL}^{-1}}{\text { Enantiomer }}$}} & \multicolumn{4}{|c|}{ Calibration line $^{\text {b) }}$} \\
\hline & & & & & \multicolumn{2}{|l|}{$S$-enantiomer } & \multicolumn{2}{|l|}{$R$-enantiomer } \\
\hline & $S$ & $R$ & $S$ & $R$ & Equation & $R^{2}$ & Equation & $R^{2}$ \\
\hline $16: 0$ & 0.2 & 0.2 & 0.66 & 0.66 & $y=1061175 x-736213$ & 0.9967 & $y=953826 x-250272$ & 0.9997 \\
\hline $18: 0$ & 0.2 & 0.2 & 0.66 & 0.66 & $y=743751 x-549055$ & 0.9978 & $y=699722 x-151986$ & 0.9985 \\
\hline $18: 1$ & 0.2 & 0.2 & 0.66 & 0.66 & $y=802928 x-275120$ & 0.9993 & $y=801020 x-312693$ & 0.9988 \\
\hline $18: 2$ & 0.2 & 0.2 & 0.66 & 0.66 & $y=954918 x-519142$ & 0.9980 & $y=984471 x-672675$ & 0.9973 \\
\hline $18: 3$ & 0.2 & 0.2 & 0.66 & 0.66 & $y=580746 x-234941$ & 0.9984 & $y=588035 x-173547$ & 0.9990 \\
\hline
\end{tabular}

a) Defined as $S / N=3$ for LOD and 10 for LOQ based on $5 \mu \mathrm{L}$ injection of the standard GE solution at a concentration of 0.2 $\mu \mathrm{g} \mathrm{mL}^{-1}$. b) Calculated from the equation $y=\mathrm{A} x+\mathrm{B}$, where $x$ is the injected concentration $\left(\mu \mathrm{g} \mathrm{mL} \mathrm{m}^{-1}\right), y$ is the peak area, $\mathrm{A}$ is the slope, and $\mathrm{B}$ is the intercept in the range between 0.5 and $50 \mu \mathrm{g} \mathrm{mL}^{-1}\left(0.5,1,5,10,20 \mathrm{and}_{50 \mu \mathrm{g} \mathrm{mL}}^{-1}\right)$.
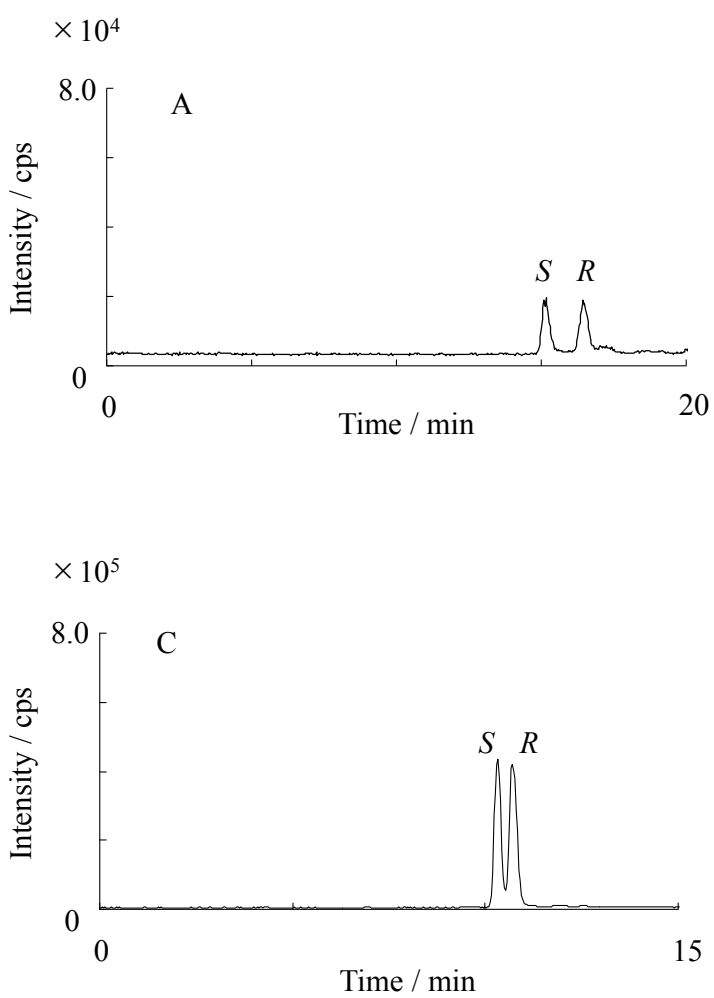
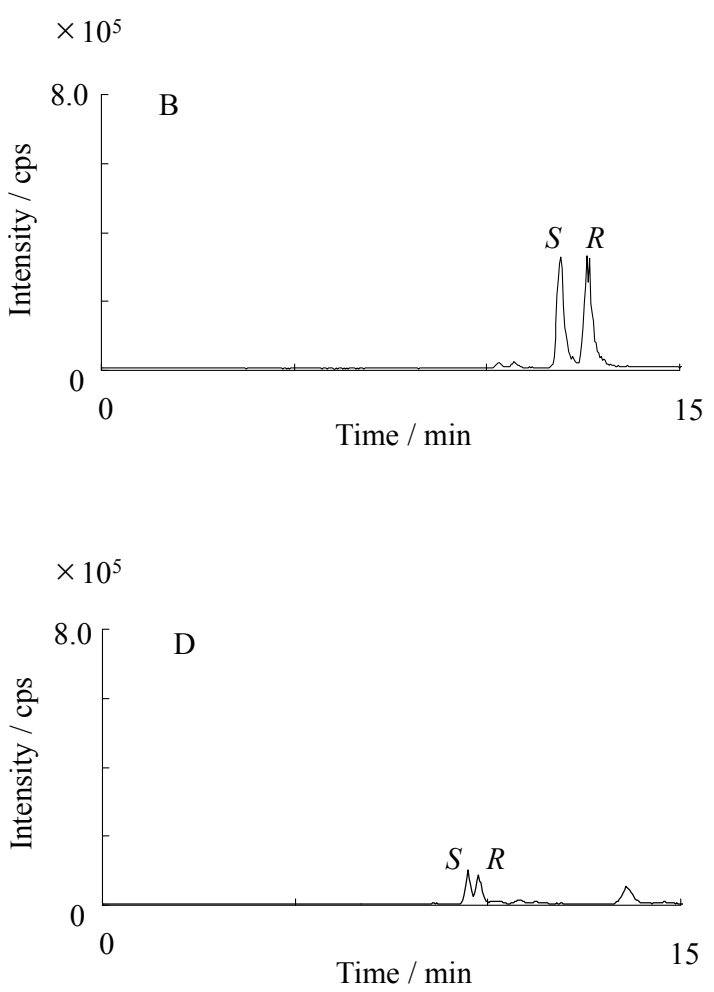

Fig. 3 Chiral-phase HPLC/APCI-MS profiles (selected ion monitoring of $[\mathrm{M}+\mathrm{H}]^{+}$) of the glycidyl fatty acid esters from a diacylglycerol-rich oil (DAG oil)

A, glycidyl palmitate $(m / z$ 313); B, glycidyl oleate $(m / z 339)$; C, glycidyl linoleate $(m / z \quad 337)$; D, glycidyl linolenate $(m / z$ 335). Glycidyl stearate is not shown. Chiral-phase HPLC-MS conditions are the same as those in Fig. 2.

キラル HPLC/APCI-MS を用いて，DAG 油中の GE を分 析して得られたクロマトグラムを Fig. 3 に示す. 濃縮や単 離などの前処理を行わずに GE を検出するために, $600 \mu \mathrm{g}$ の試料油をカラムに注入した。 その結果, 試料に含まれる 5 種の主要な GE のそれぞれの光学異性体は, 25 分以内に ほぼ完全に分離して溶出し（18：0-GEのクロマトグラムは 省略), 試料注入量の分離に及ぼす悪影響はほとんど認め られなかった. 得られた各 GE の光学異性体含量を Table 3 に示す。 DAG 油の主成分である 1,3-DAG を構成する主な
脂肪酸は, $16: 0$ (総脂肪酸中 $3.4 \%), 18: 0$ (同 $1.1 \%$ ), $18: 1$ (同 $29.9 \%$ ), $18: 2$ (同 $59.1 \%$ ), 18:3（同 $5.2 \%$ ) であることが報告されている ${ }^{13)}$ 。この脂肪酸組成を反映し て GE も 18 : 2-GE が最も高く（総 GE 中 $44.9 \%$ ), 次いで 18 : 1-GE（同 $40.5 \%$ ), 18 : 3-GE（同 $10.4 \%$ ), 16 : 0-GE (同 $2.1 \%$ ), $18: 0-\mathrm{GE}$ (同 $2.1 \%$ ) であった. いずれの $\mathrm{GE}$ についても, $(S)$ - 異性体と $(R)$ - 異性体はほぼ等量存在し た. 試料油中の GEの総含量は $238 \mu \mathrm{g} \mathrm{g}^{-1}$ であり, GEを 固相抽出法で濃縮してから分析する方法で得られた值 
Table 3 Levels of enantiomeric glycidyl fatty acid esters (GE) in a diacylglycerol-rich oil $\left(\mu \mathrm{g} \mathrm{g}^{-1}\right)$

\begin{tabular}{cccrr}
\hline \multirow{2}{*}{ GE } & \multicolumn{3}{c}{ This study } & Previous study $^{\text {b) }}$ \\
\cline { 2 - 4 } & S-enatiomer & $R$-enantiomer & $S+R^{\text {a) }}$ & \\
\hline $16: 0$ & 2.4 & 2.3 & 4.7 & 6 \\
$18: 0$ & 3.1 & 2.0 & 5.1 & $<5$ \\
$18: 1$ & 48.9 & 47.4 & 96.3 & 94 \\
$18: 2$ & 52.6 & 54.2 & 106.8 & 132 \\
$18: 3$ & 13.0 & 11.7 & 24.7 & 32 \\
Total & 120.0 & 117.6 & 237.6 & 269 \\
\hline
\end{tabular}

a) Sum of $S$ - and $R$-enantiomers. $\quad$ b) Data from Masukawa et $a l^{4)}$.<smiles>[R]C(=O)OC[C@@H](CO)[C@H]([CH])OO</smiles>

(R)-1-monoacylglycerol<smiles>[R]C(=O)O[C@@H]([2H])COO</smiles>

2-monoacylglycerol isomerization<smiles>[R]C(=O)OCC[C@]([2H])(O)CO</smiles>

(S)-1-monoacylglycerol

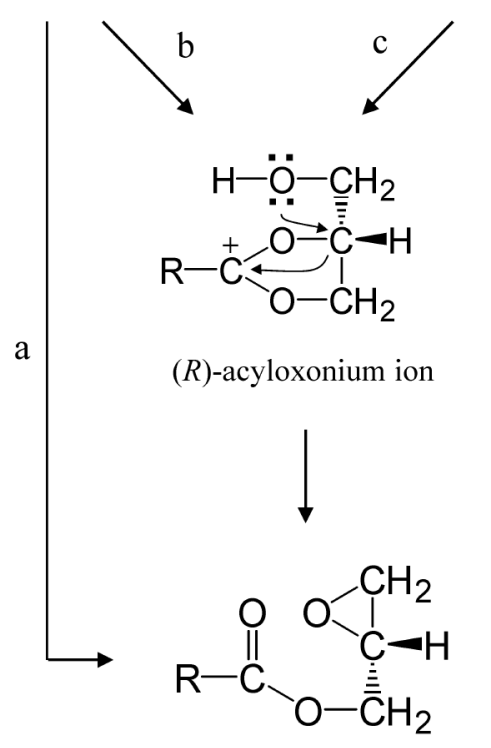

(R)-glycidyl fatty acid ester

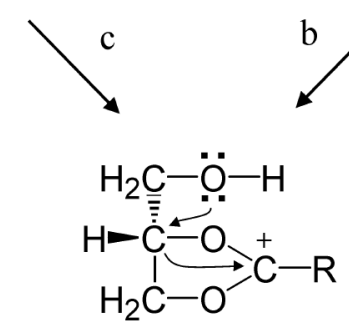

$(S)$-acyloxonium ion

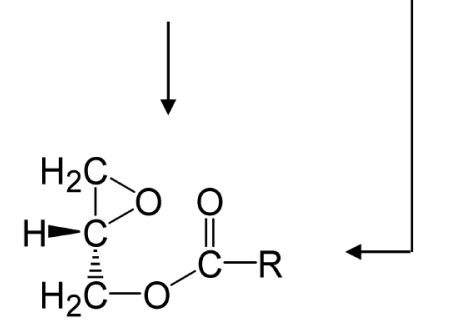

(S)-glycidyl fatty acid ester

Fig. 4 Possible mechanism of formation of enantiomeric glycidyl fatty acid esters from refined edible oils

$\left(264 \mu \mathrm{g} \mathrm{g}^{-1}\right)^{4)}$ と比較して幾分小さかった.この違いは不飽 和度が高く, かつ主要成分である $18:$ 2-GE と $18: 3-G E に$ おいて明瞭であった（Table 3). 今後, 同一試料を両方法 で分析して結果を比較することが必要であると考えられ る.

DAG 油は他の食用油に比べて GE を数十倍多く含む ${ }^{4)}$ とから本法での検出が容易であったが, 本法を極微量 $(0.1$ 〜 $\left.0.5 \mu \mathrm{g} \mathrm{g}^{-1}\right)$ の GE を含むとされる精製大豆油や精製ナ 夕ネ油など ${ }^{14)}$ 一般の食用油に広く適用するにはあらかじ め GE を濃縮したり, より高感度の MS 装置を使用するこ とが有効であると考えられる。

\section{3・4 GE 光学異性体の生成機構の推定}

$\mathrm{GE}$ は食用油の脱臭工程において, TAG と DAG 由来のモ ノアシルグリセロール (MAG) から脱水またはアシルオキ ソニウムイオンの形成を経て生成すると考えられている

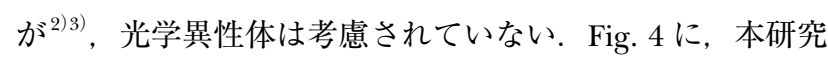
において推定した GE 光学異性体の生成機構を示す. DAG 油の主な原料である大豆油とナタネ油の TAGの $s n-1$ 位と $s n-3$ 位に結合する脂肪酸の組成はおおむね等しいことか $ら^{15)}$, DAG 油から生成する 1-MAGも $(S)$-1-MAG（sn-1MAG）と $(R)-1-\mathrm{MAG}(s n-3-\mathrm{MAG})$ のほぼ等量混合物であ ると考えられる. TAG 及び DAG からは 2-MAG も生成する 
が, これは熱力学的により安定な $(S)-1-\mathrm{MAG}$ と $(R)-1-\mathrm{MAG}$ に容易に異性化 (ラセミ化)する ${ }^{16)}$. MAGのヒドロキシル 基の脱水により，(S)-1-MAG からは $(S)$-GE が, $(R)-1-\mathrm{MAG}$ からは $(R)-\mathrm{GE}$ が生成すると推定される（経路 a)。した がって，（R)- 異性体と（ $S$ ) - 異性体のほぼ等量混合物であ る MAGからは GEのほぼラセミ体が生成する。一方, (S)-1-MAG からは $(S)$-アシルオキソニウムイオンを経て (S)-GE が, (R)-1-MAG からは $(R)$-アシルオキソニウムイ オンを経て $(R)-\mathrm{GE}$ がそれぞれ生成すると推定される（経 路 b). したがって，この場合も生成する GE はほぼラセミ 体である. 2-MAG から生成するアシルオキソニウムイオン は $(R)$ - 異性体と $(S)$ - 異性体のほほ等量混合物であると推 定されることから (経路 $\mathrm{c}$ ), 得られる GEもほぼラセミ体 となる.これらのことから, $\mathrm{DAG}$ 油に含まれる $\mathrm{GE}$ は, $R$ 配 置と $S$ 配置の異性体のほぼ等量混合物から構成されるもの と考えられる.

$$
4 \text { 結 言 }
$$

本研究ではキラル逆相 HPLC を用いて, 炭素数と二重結 合数の異なる GEの光学異性体分離に初めて成功した。こ の方法に APCI-MS を併用して DAG 油中に含まれる微量の $\mathrm{GE}$ 光学異性体をあらかじめ濃縮することなしに SIM モー ドで直接分析した結果，5種の GE（16：0-GE，18：0-GE, $18: 1-G E, 18: 2-G E, 18: 3-G E)$ の光学異性体がそれぞれ 明瞭に分離され, 10 成分の一斉分析が可能となった. 各光 学異性体含量は DAG 油の脂肪酸組成を反映して 18 : 2-GE

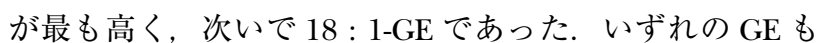
$R$ 配置と $S$ 配置の異性体のほぼ等量混合物であったが, こ のことは, GE の前駆体である 1-MAG がほぼラセミ体であ ることに起因すると考えられる.

\section{謝辞}

本研究の一部は, 財団法人旗影会の助成により行われ た。

\section{文献}

1) Federal Institute for Risk Assessment (BfR) : “Initial evaluation of the assessment of levels of glycidol fatty acid esters detected in refined vegetable fats (in German)", <http://www.bfr.bund.de/cm/343/erste einschaetzung_von_glycidol_fettsaeureestern.pdf $>$, BfR Opinion No. 007/2009, 10 March (2009).

2) C. G. Hamlet, L. Asuncion, J. Velíšek, M. Doležal, Z. Zelinková, C. Crews : Eur. J. Lipid Sci. Technol., 113, 279 (2011).

3) R. Weißhaar, R. Perz: Eur. J. Lipid Sci. Technol., 112, 158 (2010).

4) Y. Masukawa, H. Shiro, S. Nakamura, N. Kondo, N. Jin, N. Suzuki, N. Ooi, N. Kudo : J. Oleo Sci., 59, 81 (2010).

5) Y. Masukawa, H. Shiro, N. Kondo, N. Kudo : J. Am. Oil Chem. Soc., 88, 15 (2011).

6) Deutsche Gesellschaft für Fettwissenschaft e. V. : "DFG Standard Methods C III 18 (09). Ester-bound 3-chloropropane-1,2-diol (3-MCPD esters) and glycidol (glycidyl esters). Determination in fats and oils by GC-MS.", <www.dgfett.de/methods/>.

7) T. Yasukawa, Y. Katsuragi : "Diacylglycerol Oil (2nd Edition)", Edited by Y. Katsuragi, T. Yasukawa, N. Matsuo, B. D. Flickinger, I. Tokimitsu, M. G. Matlock, p. 1 (2008), (AOCS Press, Urbana).

8) Chiral Technologies Europe: "Instruction manual for Chiralpak ${ }^{\circledR}$ IA columns”, < http://www.chiral.fr >.

9) S. Moranhte-Zarcero, I. del Hierro, M. Fajardo, I. Sierra : Anal. Chim. Acta, 566, 185 (2006).

10) T. E. Beesley, R. P. W. Scott (Eds.) : “Chiral Chromatography”, p. 239, (1998), (John Wiley \& Sons, New York).

11) Y. Itabashi : "HPLC of Acyl Lipids", Edited by J.-T. Lin, T. A. McKeon, p. 167 (2005), (HNB Publishing, New York).

12) Y. Itabashi : Chromatography, 32, 59 (2011).

13) 鷹野浩之, 板橋 豊: 分析化学 (Bunseki Kagaku), 51, 437 (2002).

14) R. Weißhaar: Eur. J. Lipid Sci. Technol., 113, 304 (2011).

15) W. C. Breckenridge : "Handbook of Lipid Research 1. Fatty Acids and Glycerides", Edited by A. Kuksis, p. 197, (1978), (Plenum Press, New York).

16) F. H. Mattson, R. A. Volpenhein : J. Lipid Res., 3, 281 (1962). 


\title{
Analysis of Enantiomeric Glycidyl Fatty Acid Esters by Chiral-phase HPLC/MS with Atmospheric Pressure Chemical Ionization
}

\author{
Satoshi YoshiokA ${ }^{1}$, Kazuhiko Nishimura ${ }^{2}$, Takeji Takamura ${ }^{3}$, Masumi Suzui ${ }^{4}$, \\ Hiroyuki TSUDA ${ }^{4}$ and Yutaka ITABASHI ${ }^{\circledR 5}$ \\ ${ }^{\circledR}$ E-mail : yutaka@fish.hokudai.ac.jp
}

${ }^{1}$ Division of Marine Life Science, Graduate School of Fisheries Sciences, Hokkaido University, 3-1-1, Minatocho, Hakodate-shi, Hokkaido 041-8611

${ }^{2}$ Hokkaido Institute of Public Health, Kita 19-Nishi 12, Kita-ku, Sapporo-shi, Hokkaido 060-0819

${ }^{3}$ Kanagawa Institute of Technology, 1030, Simoogino, Atsugi-shi, Kanagawa 243-0292

${ }^{4}$ Graduate School of Medical Sciences and Medical School, Nagoya City University, 1, Kawasumi, Mizuho-cho, Mizuho-ku, Nagoya-shi, Aichi 467-8601

${ }^{5}$ Division of Marine Life Science, Faculty of Fisheries Sciences, Hokkaido University, 3-1-1, Minato-cho, Hakodate-shi, Hokkaido 041-8611

(Received April 13, 2012 ; Accepted May 21, 2012)

A simple and selective method was developed for the determination of enantiomeric glycidyl fatty acid esters (GE) in refined edible oils, which are undesirable trace contaminants formed during refining processes. For this purpose, chiral-phase high-performance liquid chromatography (HPLC) was performed with a column containing amylose tris(3,5dimethylphenylcarbamate) as a chiral selector, using an acetonitrile/methanol mixture as the mobile phase, which gave clear enantiomer resolution of synthetic saturated and unsaturated GE racemates. This was followed by on-line atmospheric pressure chemical ionization mass spectrometry (APCI/MS) to obtain prominent protonated $[\mathrm{M}+\mathrm{H}]^{+}$molecules, by which individual GE molecules could be identified and quantified. The quantification of GE enantiomers was performed in the selected ion monitoring (SIM) of $[\mathrm{M}+\mathrm{H}]^{+}$. This chiralphase HPLC/APCI-MS-SIM method was standardized with synthetic GE racemates, and applied to the separation, identification and quantification of individual GE enantiomers in a commercial diacylglycerol (DAG)-rich oil produced originally from soybean oil and rapeseed oil. The results clearly showed that the DAG-rich oil contained almost equal amounts of $R$ and $S$-enantiomers of glycidyl palmitate (16:0-GE), stearate (18:0-GE), oleate (18:1-GE), linoleate (18:2-GE), and linolenate (18:3-GE), suggesting that both enantiomers would be formed from the corresponding almost racemic 1-monoacylglycerols. The most predominant GE was 18 : 2-GE, followed by $18: 1-\mathrm{GE}$, which accounted for 107 and $25 \mu \mathrm{g} \mathrm{g}^{-1}$, respectively, reflecting the fatty acid composition of the DAG oil.

Keywords : glycidyl fatty acid ester ; enantiomer ; diacylglycerol-rich oil ; chiral-phase HPLC ; atmospheric pressure chemical ionization mass spectrometry. 